\title{
METAPHORS AND ARGUMENTS TO SEMANTIC POLITICAL METAPHORS IN INDONESIAN MASS MEDIA AND ITS PERSUASIVE EFFECT TOWARD READERS
}

\author{
Yuli Widiana and Roro Arielia Yustisiana \\ widianayuli@yahoo.com, lia.6606@gmail.com \\ English Department, Faculty of Letters, Widya Mandala Catholic \\ University, Madiun, Indonesia
}

\begin{abstract}
The research is aimed to describe kinds of political metaphors and their metaphorical meanings. Furthermore, the persuasive effect of political metaphors in mass media toward the readers is also analyzed based on certain parameters. The pragmatic equivalent method and the referential equivalent method are applied to analyze the data. The kinds of political metaphors include metaphors with nature as a parable, metaphors with plants as a parable, metaphors with terms from various fields, metaphors with common things as a parable, metaphors with particular verbs, and metaphors with particular adjectives. The readers could comprehend political metaphors well although their interest in political news is low. Apparently, the persuasive effect of political metaphors on the public is high. It becomes a trigger for people to take action to create a better political atmosphere.
\end{abstract}

Key words: political metaphor, mass media, persuasive effect

Abstrak: Penelitian ini bertujuan menggambarkan jenis-jenis metafora
politik dan makna metaforisnya. Lebih jauh, efek persuasif metafora
politik dalam media massa terhadap pembaca juga dianalisis berdasarkan
parameter tertentu. Metode padan pragmatis dan metode padan
referensial diterapkan untuk menganalisis data. Jenis-jenis metafora politik
meliputi metafora dengan perumpamaan alam. metafora dengan
perumpamaan tumbuhan, metafora dengan istilah dari berbagai bidang,
metafora dengan perumpamaan benda umum, metafora dengan kata kerja
tertentu, dan metafora dengan kata sifat. Pembaca memahami metafora 
politik dengan baik meskipun ketertarikan mereka pada berita politik rendah. Pada kenyataannya, efek persuasif metafora politik terhadap masyarakat untuk mengambil tindakan adalah dalam rangka memperbaiki atmosfir politik yang lebih baik.

Kata kunci: metafora politik, media massa, efek persuasif

\section{INTRODUCTION}

Meaning in a pragmatic point of view, and it is one of the important discussions in the field of linguistics. The research of pragmatic meaning is related to various aspects of external linguistics such as culture and tradition that could give huge influence in the process of interpreting meaning. It is this case that becomes the basic consideration to classify meaning with different approaches.

One of the interesting discussions in pragmatics is metaphors. Metaphors are not only found in literary works but also in political news and in mass media. One of the examples is the headline taken from the political news, Hubungan Diplomatik Indonesia-Australia Memanas. The example shows that the diplomatic relationship between the two countries is compared to fire because there is a political conflict between both countries. Fire is the best description for anger, describing that the diplomatic relationship between Indonesia-Australia is illustrated by the metaphor memanas 'inflamed'. The use of metaphor in mass media is aimed to attract more readers to read the news.

Politics always involves various activities to influence the public, specifically in political campaigns. At this moment, people tend to use sentences which contain metaphors to influence the public in an efficient way. Therefore, metaphors in political campaigns or political news are used to make the campaign or news more interesting so that it will be more effective to influence the public to follow certain political ideas. The power of words is believed to be a huge power to spread political ideas, inspire people, and attract them to support political ideas which are campaigned.

The research of metaphors in politics has already conducted before by Andrew J. Gallagher (2012). In his research, Gallagher discusses political metaphors in USA by using some data from political speeches of some American presidents. Besides that, Domínguez (2015) who also conducted the 
Widiana, Y. \& Yustisiana, R.A. Metaphors and Arguments to Semantic Political 207 Metaphors in Indonesian Mass Media \& Its Persuasive Effect to Readers

research on metaphors stated that when there is a strong media impact on a population, different metaphoric images about the event are quickly created and popularized. Furthermore, Domínguez (2015) also stated that different metaphors compete and the fittest occupy a place in the collective imagination, gradually forcing others aside. Therefore, a new communication frame boosts the emergence of new metaphors, which then start evolving and competing with each other (Domínguez, 2015, p. 247).

The research about metaphors in political news in Indonesian mass media is conducted as further research which is aimed to describe the kinds and meanings of metaphors with the Indonesian cultural background. The research measures the persuasive effect of the use of metaphors in political news in influencing the readers to do such actions in order to create a better political atmosphere. Consequently, this research could enrich the research in the field of pragmatics, especially about metaphors in order to give valuable contribution to journalism in relation to political matters.

\section{LITERATURE REVIEW}

Based on its characteristics, metaphors are one of the figurative languages. Metaphors have particular features which make them different from any other figurative languages like idioms, personifications, analogies, and similes. Lakoff and Johnson introduced structural metaphors, cases where one concept is metaphorically structured in terms of another (1980, p. 14). In line with the previous theory, Mooij stated that metaphors are to be looked upon as a bridge or implicit comparison (1976, p. 29). However, the things which are compared must have similar categories in certain ways. Whereas, O'Grady defined metaphors as understanding of one concept in terms of another (2005, p. 211).

Generally, metaphors are created by using the comparison of two different things which is not related at all but both have certain features which may describe similar characteristics in meaning. One of the examples of metaphors is time is money. In this case, time is compared to money as both of them are very important in life so that we are not supposed to waste them. However, time and money are two different things since time is abstract and money is real. Apparently, identifying metaphors sometimes is not an easy task. However, there is a particular aspect that we could take into consideration to determine whether such an expression is metaphors or not. Mooij (1976, 
p.18) explains that strangeness or surprisingness of a metaphorical expression in its context may be the aspect to identify metaphors.

Metaphors could be classified in various categories as the concept in such a language may be related to various interpretations and associations. One of the concepts which are used to determine the kinds of metaphors is spatial metaphors, a kind of metaphors which involves the use of words that are primarily associated with spatial orientation to talk about physical and psychological states (O'Grady, 2005, p.212). The example of spatial metaphors in relation to psychological condition or emotion is I'm feeling down (O'Grady et al, 2005 , p. 212). The concept of spatial metaphors shows a close relationship between psychological emotion and spatial condition or expression of up and down. In this case, the expression of feeling down is related to sadness and disappointment.

The similar concept of metaphors is what is called orientational metaphors. This also includes the concept of spatial metaphors. Furthermore, Lakoff and Johnson explain that such metaphorical orientations are not arbitrary. They have a basis in our physical and cultural experience. Though the polar oppositions up-down, in-out, etc., are physical in nature, the orientational metaphors can vary from culture to culture (1980, p.14).

Metaphors could also be analyzed based on their structure. Concerning to this matter, metaphors consist of: wehicle as the item(s) used metaphorically, tenor as the metaphorical meaning of the vehicle, and ground as the basis for the metaphorical extension, essentially the common elements of meaning, which license the metaphor (Cruse, 2000, p.203). For example, the leg of the table, in this case, leg is the vehicle. Meanwhile, the tenor refers to something in the lower position which is related to the vehicle as leg is always in a lower position. The classification of metaphors and its meaning interpretation must consider various aspects as metaphors are closely related to context, field, and culture which build those metaphors. Hence, the meaning of metaphors in one language might be different in other languages.

\section{METHOD}

The research uses the data in written form which are taken from Kompas, a national newspaper which is published in Indonesia. Hence, the technique of collecting data is library research. The Kompas newspaper is 
Widiana, Y. \& Yustisiana, R.A. Metaphors and Arguments to Semantic Political 209 Metaphors in Indonesian Mass Media \& Its Persuasive Effect to Readers

chosen as the source of data in this research because the newspaper publishes the current political news daily. There are many political metaphors found in the column of political news in this newspaper. Because this national newspaper has many readers all around Indonesia, Kompas newspaper could be a valid source of data in the research of political metaphors.

Since the number of data is not too large, only 49 sentences, all of the data are analyzed by using Total Sampling techniques. The unit of analysis in this research is all sentences which contain political metaphors. Next, a questionnaire method is applied to collect the data from the respondents concerning their interest to read political news, their comprehension on political metaphors, and how far the readers want to take action to make the condition of politics better. The result of the questionnaire shows the degree of persuasive effect which is built by political metaphors used in mass media.

The method of data analysis in this research is equivalent method. The technique of data analysis which is applied in this research is the pragmatic equivalent method which analyzes data based on external factors of language like context, background, and speaker (Djajasudarma, 1993, p. 58). This technique is applied to analyze the meanings of political metaphors which are found in Kompas newspaper based on certain variables. In the research, the unit of analysis is observed as relationships among characteristics. The varying characteristics of units that take on different values, categories, or attributes for different observations are called variables (Singleton, Jr. \& Straits, 1999, p. 70). Thus, variables may be various depending on the design of the research. The variables in this research are the external aspects of linguistics that may build political metaphors such as things surrounding us and events. Those variables are taken into consideration to determine the kinds of political metaphors found in the data. Furthermore, the variables are also used to explain the meaning of political metaphors.

In the research, pragmatic equivalent method is also applied to analyze and measure the persuasive effect of the use of political metaphors towards the readers. Next, the referential equivalent method is also used in this research to determine the kinds of metaphors which are found in political news. This method is applied to classify the kinds of metaphors based on their characteristics and meanings. 
210 Celt, Volume 15, Number 2, December 2015, pp. 205-221

\section{FINDINGS}

The kinds of political metaphors which are used in Kompas newspaper consist of political metaphors with nature as a parable, political metaphors with plants as a parable, political metaphors with the terms from various fields, political metaphors with common things as a parable, political metaphors with particular verbs, and political metaphors with particular adjectives. Parables of nature and plants are often found in Indonesian political metaphors since Indonesia is an agricultural country. Meanwhile, specific terms from different fields are also used as parables in Indonesian political metaphors. The terms taken various fields contain metaphorical meanings which still show similarities in characteristics with their literal meanings. Next, verbs and adjectives which are used as parables in political metaphors reflect personified meanings which are related to some actions done by people or animals and the characteristics of living creatures.

In this research, the persuasive effect of the use of political metaphors in mass media towards readers is measured by using some parameters based on the questionnaire distributed to respondents. There are 100 respondents which are taken from the two governmental institutions. They are from the Department of Information and Communication of East Java Province and the Health Department of the City of Cimahi West Java Province. The respondents for this research must fulfil certain criteria such as the age is between 20 to more than 49 years old; male and female; the educational background is high school graduates, Diploma graduates, Bachelor degree, and master degree; the period of work is between less than two years and more than seven years with the employment status of civil servant and contract employees. The parameter to measure the persuasive effect of political metaphors is based on some components such as the level of interest on political news, the level of comprehending political metaphor, and the level of interest to take some positive actions as a result of persuasive effect caused by political metaphors used in mass media.

Based on the questionnaire, the respondents are not really interested in reading political news. However, it does not influence the level of their comprehension on political metaphors. In other words, the readers could understand political metaphors well although they are not really fond of reading political news. Furthermore, political metaphors used in political news in Indonesian mass media contribute a great persuasive effect towards the reader that perpetuate the positive actions to fix the weaknesses in 
Widiana, Y. \& Yustisiana, R.A. Metaphors and Arguments to Semantic Political 211 Metaphors in Indonesian Mass Media \& Its Persuasive Effect to Readers

Indonesian politics in order to build a better political atmosphere that would contribute welfare for the society.

\section{A. Kinds of political metaphors}

The kinds of political metaphors found in mass media are classified based on the kinds of parables which are used as metaphors. The data analysis to classify the political metaphor is conducted by applying referential equivalent method. The occurrence of various political metaphors in Indonesian mass media supports the opinion of Domínguez (2015) about a strong media impact on a population which could create and popularize different metaphoric images.

A detailed discussion about the classification of political metaphors in Indonesian mass media is provided in the following part including the relevant examples.

\section{B. Political metaphors with nature as a parable}

Nature is often used as a parable in metaphors. Things in nature like wind, lightning, and fire may function as a vehicle of political metaphors. Thus, the vehicle shows a particular meaning which is called tenor. Basically, tenor is formed based on ground as a basic of metaphorical extension (Lakoffand Johnson, 1980). The following example makes the statement clear:

(1) Politisi di Negara manapun pasti menebar "angin surga" saat kampanye.

Political metaphor angin surga means breaking vows. The metaphor occurs as there are many politicians who often make promises in political campaigns but when they are elected in certain governmental or political positions, they never fulfil their promise to build the societies welfare. In this example, angin or wind is used as a parable as it has the characteristics of easily disappearing. It fits to describe how easy the politicians forget and break their vows. Meanwhile, surga or heaven which contains the meaning of comfortable and wonderful is used as a parable to describe how great the vows made by the politicians are.

A similar political metaphor is as follows:

(2) Akhir cerita Partai Golkar tinggal menunggu waktu. Membiarkan akarnya terbakar bara api, atau sebaliknya, islah tercipta bersendikan kebesaran hati pemimpinnya. 
The parables petir (lightning) and akar (root) describe a conflict which causes anger and disappointment. Next, the thing like api or fire is used to build a parable which shows anger and conflict as fire contains heat.

\section{Political metaphors with plants as a parable}

Parables by using plants are frequently found in political metaphors in Indonesian mass media. Basically, plants have a close relationship with Indonesian culture because of its agricultural state. The following example is the political metaphor with the subject of plants as a parable:

(3) Bara api perlahan tapi pasti bakal terus merambat di akar "Pohon Beringin". Antara pemimpin baru hasil munas di pesisir Pantai Nusa Dua (Bali) dan di Pantai Ancol (Jakarta) sama-sama bersikeras membawa kasus sengketa ke pemimpinan kembar ke pengadilan.

The parable pohon beringin (banyan tree) refers to the symbol of one of political parties in Indonesia. A banyan tree is a common tree that could be found in Indonesia. Its thick leaves could be a shelter for everything under it. It symbolizes a guardianship of a leader towards their subordinates. Moreover, the banyan tree is also used as a symbol of political party since this tree is a strong tree which can live long so that it symbolizes a big political party which has strong influence in Indonesian politics for a long time.

\section{Political metaphors with terms from various fields}

The terms from various fields are often used as political metaphors. The terms refer to certain metaphorical meanings which are related to politics. However, the basic characteristics of the literal meanings are still seen in their metaphorical meaning.

One of the terms which are used in political metaphors is exemplified in the following datum:

(4) Kiai menjadi sentral dalam pergerakan NU bersama dunia pesantren yang merupakan pusat pendidikan dan cagar budaya NU.

The term cagar budaya (cultural conservation) means the conservation of all cultural assets. In this case, cagar budaya refers to the protection and conservation of the culture of Islamic organization of Nahdlatul Ulama which has a huge role in Indonesian politics. 
Widiana, Y. \& Yustisiana, R.A. Metaphors and Arguments to Semantic Political 213 Metaphors in Indonesian Mass Media \& Its Persuasive Effect to Readers

Some political metaphors use human beings as parables which refer to particular metaphorical meanings. The following datum is the related example:

(5) Direktur Eksekutif Indikator Politik Indonesia Burhanuddin Muhtadi mengatakan, KIH, pendukung pemerintah, akhir-akhir ini tampil sebagai pemeran antagonis dalam drama konflik KPK-Polri.

The term pemeran antagonis (antagonist role) contains metaphorical meaning about the opposition group. The term is commonly used in the field of cinematography. Both antagonist role and opposition group have similar characteristics and are against each other. The forestry term is also used metaphorically in the political metaphor as follows:

(6) Pelaporan didasari dugaan Zulkarnain melakukan tebang pilih atas penetapan 186 tersangka yang merupakan pengguna dan penerima anggaran P2SEM.

Political metaphor in this example uses a parable tebang pilih which is originally a term in science field of forestry. The metaphorical meaning in the term is the determination of the accused without any proper proof. The term from science is also used in the following political metaphor:

(7) Namun, kita saat itu juga sadar bahwa politik bukanlah hitungan matematika $2+2=4$.

Mathematics is an exact science. In the example, politics is illustrated as something which is not exact so that it is different from mathematics. Next, the term from the transportation field is also used in the following data:

(8) Namun, semua merasakan jarak pandang terlalu pendek. Arahannya belum terlalu jelas karena ada realitas politik berlapis-lapis," ujarnya.

The term jarak pandang (visibility) is used metaphorically which means limited political view causes political vision and mission to become unclear. The other specific term which is used in political metaphors is taken from medical register as it is exemplified in the following datum:

(9) Sejumlah ketentuan masih belum disepakati DPR, seperti persyaratan ambang batas kemenangan. 
The term ambang batas (threshold) in medical terms is used to measure someone's threshold of pain. In political metaphors, ambang batas is used to measure the victory in the general election. Furthermore, political metaphors also borrow terms from psychology as parables. One of them occurs in the following datum:

(10) Kalimat di laman Facebook-nya itu, patut diduga gambaran dari upaya Jokowi untuk menahan ego kelembagaan seperti yang tengah terjadi antara Polri dan KPK.

The meaning of ego in psychology refers to the personality of someone who is selfish. The term ego kelembagaan has a metaphorical meaning of someone possessing the characteristics who tends to pay attention more to the importance of organization than society. The term taken from governmental register is used in the following political metaphors:

(11) Dibawah manuskrip berjudul "Revolusi Mental", masyarakat diinisiasi lewat sejumlah sekuel dramatik yang hadir ke hadapannya.

Revolusi Mental (mental revolution) is the idea which is campaigned by Indonesian President Joko Widodo.-It refers to the massive mental and characteristic revolution of the nation that needs to occur in order for Indonesia to become a better nation.

\section{E. Political metaphors with common things as a parable}

The things which are used in daily activities could also be used as parables in political metaphors. They would have specific metaphorical meanings based on the context. One of the examples is provided in the following datum:

(12) Mulai dari sebuah tulisan di blog Kompasiana hingga persoalan tugas masa lalu jadi senjata untuk melaporkan tiga unsur pimpinan KPK tersisa ke polisi.

Basically, senjata (weapon) is the thing which is used to shoot and attack the target. In the example, weapon is used metaphorically to describe a piece of evidence that could be used to attack someone if brought to court. Therefore, the characteristic of weapon which is used to attack the target is used both in literal meaning and in metaphorical meaning. Next, the other common thing which is used in political metaphors could be seen in the datum as follows: 
Widiana, Y. \& Yustisiana, R.A. Metaphors and Arguments to Semantic Political 215 Metaphors in Indonesian Mass Media \& Its Persuasive Effect to Readers

(13) Kebijakan Basuki tersebut bakal menjadi magnet eksodus PNS instansi lain ke Pemprov DKI Jakarta.

Based on the context, magnet is a parable of attractiveness to make civil servants interested in moving and working in the Jakarta Province. The characteristic of magnets, to pull the things toward it, is best used metaphorically to describe the attractiveness to work in the governmental institutions of Jakarta Province. Furthermore, the terms which have positive meanings may have negative meanings when they are used metaphorically. The following example is best used to explain this matter:

(14) "Publik bisa menilai ada 'permainan' di antara panitia seleksi," ujarnya.

To gain victory in the game, certain strategies are needed. This characteristic is seen in the use of the term permainan or game in political metaphor provided in the example. In this case, permainan or game means the trick which is done to win the election of certain position in government. Furthermore, parts of the body may have the metaphorical meaning as illustrated in the following context:

(15) Singkat kata, wajah NU yang-kuat dengan karakter Tawasut (moderat), Tasamuh (toleran), Tawazun (proporsional), dan I'tidal (adil) kini hadir lebih sering di dunianya.

The term wajah (face) is used as political metaphor to give the image of such an organization. Apparently, it fits with the characteristic of face as part of the body that could give a clear image of someone. Moreover, the culinary term is also used in political metaphors as a parable as it is provided in the following datum:

(16) Sebab, tak sedikit RUU yang tumpang tindih dalam artian judul RUU berbeda, tetapi semangat atau temanya sama. "Kalau irisan-irisan itu dihapus, dirapikan, jumlahnya tak sebanyak itu," tuturnya.

In culinary terms, irisan (sliced) is a thin piece of food with almost similar size. To illustrate small rules which have nearly similar content, the term irisan, is used to make readers easier to get a clear picture to comprehend the metaphor. Apparently, political metaphors often borrow terms from various fields which are even not related to politics at all. One of the examples is the term akrobat, or acrobat, which is usually used in a circus setting. The use of this term is best exemplified as follows: 
216 Celt, Volume 15, Number 2, December 2015, pp. 205-221

(17) "Rakyat lelah menyaksikan acrobat mereka," ujarnya.

In politics, acrobat may have the meaning of extreme negative actions to fulfil certain political purpose which are clearly shown to public. It fits with the literal meaning of acrobat which refers to extreme performance which is shown to an audience. The other common term which contains metaphorical meaning is shown in the following context:

(18) "Kalau (praperadilan) dikabulkan, dapat jadi lonceng kematian bagi KPK. Kalau dikabulkan satu demi satu (permohonan praperadilan tersebut), KPK bisa rontok," kata Refly.

The metaphor lonceng kematian (death knell) is often used in politics to describe the failure of such a political organization. It is related to the function of knell as an alarm to identify a certain event. The other example is provided as follows:

(19) Ia menambahkan, PKB harus menang di semua Pilkada daerah tapal kuda, termasuk Kabupaten Jember.

Daerah tapal kuda which is used as a political metaphor in the example refers to certain region which becomes the main target to gain victory in a general election. It fits with the function of horse shoes which are very important tools for horses to protect their feet so that it may be able to walk well and run fast. Metaphors in politics may also use the traditional terms taken from regional dialect as it could be seen as follows:

(20) Masa Pak Karno sangat menyenangkan. Tidak pernah ada perkara beselan ('suap').

The term beselan which is taken from Javanese dialect is frequently used in political news with the topic of bribery. In politics, beselan means everything in relation to bribery for political purposes.

\section{F. Political metaphors with particular verbs}

Political metaphors may use some particular verbs to illustrate certain things. One of the examples is as follows:

(21) Mereka akan memburu teroris pimpinan Santoso yang diduga masih berkeliaran di wilayah pegunungan Poso Pesisir Selatan dan Poso Pesisir. 
Widiana, Y. \& Yustisiana, R.A. Metaphors and Arguments to Semantic Political 217 Metaphors in Indonesian Mass Media \& Its Persuasive Effect to Readers

In daily life, memburu (to hunt) refers to catching prey which is usually an animal. In the next development, this verb also means catching prey which is not an animal. In this case, the preys are terrorists. Hunting terrorists is compared to hunting animals as it tends to be difficult as animals are easy to runaway and hide. The next example of political metaphors with particular verbs is as follows:

(22) Kondisi ini membuat fraksi-fraksi anggota KIH meradang dan menolak mengisi AKD.

Meradang (inflamed) is usually used to picturize certain desease which may cause infection in body. It could be identified by the raising of body temperature. In the example, meradang describes the flammable political condition which is caused by the protest of the members of factions. The verb which is related to the characteristics of animal is also found in political metaphor in the following context:

(23) Publik mengendus kepentingan politik menyandera kedua lembaga itu.

The word mengendus (sniff) commonly describes the behavior of a dog which has the capability to detect something by its smelling sense. In the context, mengendus means the public suspects the political matter which becomes the cause of the conflict between both organizations.

\section{G. Political metaphors with particular adjectives}

The characteristics of human beings are often used as parables in politics. The following datum is one of the examples:

(24) Menteri Sekretaris Negara Pratikno sebelumnya menepis lembaga kepresidenan terlalu gemuk.

The adjective gemuk (fat) is best used as a description of body figure to illustrate certain political conditions. In this case, a fat political organization means it has too many components which may reduce the performance of the organization.

\section{H. The persuasive effect of political metaphors in mass media toward readers}

The persuasive effect of the use of political metaphors in mass media toward readers is measured by using certain parameters. The parameters are 
determined based on the answer of 100 respondents in the questionnaire. The parameters which become the criteria to measure the persuasive effect of political metaphors are mainly based on some components such as the level of interest to read political news, the level of comprehending political metaphors, and the level of interest to perform positive actions as the cause of persuasive effect built by political metaphors in mass media.

The detailed discussion of each component of the parameters to measure the persuasive effect of political metaphors is provided in the following parts.

\section{The level of interest on political news}

Based on the answers of the respondents in the questionnaire, the level of interest to read political news is described in the following table:

Table 1:

Percentage of Level of Interest

\begin{tabular}{lc}
\hline \multicolumn{1}{c}{ The Level of Interest } & Percentage \\
\hline Interesting & $39 \%$ \\
Neutral & $50 \%$ \\
Not interesting & $11 \%$ \\
\hline
\end{tabular}

Table 1 shows that readers are not really interested in reading political news. Only 39\% of the respondents are really interested in political news. The rest, $50 \%$, is neutral in their opinion on political news and $11 \%$ of respondents consider that political news is not interesting at all.

\section{J. The level of comprehending political metaphors}

The level of comprehension concerning political metaphors may be influenced by various factors such as language mastery, reader's personal perception, and political knowledge of readers. The result based on the questionnaire concerning this matter is provided in table 2 :

Table 2:

Percentage of Level of Comprehension

\begin{tabular}{lc}
\hline \multicolumn{1}{c}{ Criteria of Comprehension } & Percentage \\
\hline Able to comprehend & $70 \%$ \\
Difficult to comprehend & $24 \%$ \\
Unable to comprehend & $9 \%$ \\
\hline
\end{tabular}


Widiana, Y. \& Yustisiana, R.A. Metaphors and Arguments to Semantic Political 219 Metaphors in Indonesian Mass Media \& Its Persuasive Effect to Readers

The results support Gallagher (2003) who stated that based on the amount of political metaphors, the rapid development of metaphors tends to describe political neutralization. Consequently, most of the metaphors are part of people's daily conversation in discussing political matters just like discussing any other matters. Therefore, political metaphors are no longer something strange because society have easily comprehended them. Table 2 obviously describes that most of the readers could comprehend political metaphors well. It is proven by the answers of the respondents in which $70 \%$ of them state that they could understand political metaphors in mass media very well. Only $24 \%$ of the respondents find difficulty in understanding political metaphors. The rest, $9 \%$ of the respondents, do not comprehend political metaphors at all. This suggests that the level of comprehending political metaphors is high. Besides that, the results suggest that the low level of interest on political news does not affect the level of comprehending political metaphors. The result also supports the theory of conceptual metaphors by Lakoff and Johnson (1980). The conceptual metaphors which blends in daily life not only influences language but also thought and action. It answers the question of why the level of comprehension of political metaphors is high although the level of the interest on political news is low.

\section{K. Persuasive effect of political metaphors toward readers}

Political metaphors which are used in political news are aimed to influence public to perform some actions to create a better political condition. The persuasive effect of political metaphors in this case is described in the following table:

Table 3:

Persuasive Effect of Political Metaphors

\begin{tabular}{lc}
\hline \multicolumn{1}{c}{ Persuasive Effect } & Percentage \\
\hline High & $67 \%$ \\
Medium & $12 \%$ \\
Low & $21 \%$ \\
\hline
\end{tabular}

The result of the questionnaire supports the opinion of Gallagher (2013). He stated that for the question of whether or not metaphor usage has an impact on the political process, logically, there are three possible effects - they may be harmful, beneficial or have no effect at all (Gallagher, 2013, p.1) Hence, the use of political metaphors in political news in Indonesian mass media contributes high persuasive effect towards the readers to conduct some actions 
to repair the weaknesses in political condition. It perpetuates the creation of better political atmosphere in Indonesia. Therefore, the political condition in Indonesia is hoped to be cleaner and healthier in order to support the continuous development of the nation that would contribute to the welfare of the society.

\section{CONCLUSION}

The kinds of political metaphors in Indonesian mass media include political metaphors with nature as a parable, political metaphors with plants as a parable, political metaphors with terms from various fields, political metaphors with common things as a parable, political metaphors with particular verbs, and political metaphors with particular adjectives. Basically, the interpretation of meaning in political metaphors still implies the similar characteristics of its literal meaning. Furthermore, although political news is not really interesting for most of the readers, it does not affect the level of comprehending political metaphors as readers are able to understand political metaphors well. The result of the research shows that persuasive effect caused by the use of political metaphors in potitical news in Indonesian mass media is high. It may be a trigger for people to conduct positive actions in order to fix the weaknesses in political condition in Indonesia. Thus, the function of media to influence public is fulfilled. It strongly suggests that the power of words would be a huge motivator for people to conduct some actions to create a better life in every way.

\section{REFERENCES}

Cruse, A. (2000). Meaning in Language: An Introduction to Semantics and Pragmatics. Oxford: Oxford University Press.

Djajasudarma,F. (1993). Metode Linguistik, Bandung: Eresco.

Domínguez, M. (2015). On the origin of metaphors. Metaphor and Symbol, A Literary Journal. 30 (3), pp. 240-255. DOI: 10.1080/10926488 .2015 .1049858

Gallagher, A. (2012). Metaphors in American politics. 1. Retrieved January 7, 2015 from http://www.political metaphors. com/metaphors-101/ 
Widiana, Y. \& Yustisiana, R.A. Metaphors and Arguments to Semantic Political 221 Metaphors in Indonesian Mass Media \& Its Persuasive Effect to Readers

Lakoff, G. \& Johnson, M. (1980). Metaphors We Live By. Chicago: The University of Chicago Press.

Mooij, J. J. A. (1976). A Study of Metaphor. Amsterdam: North Holland Publishing Company.

O'Grady, W., John, A., Mark, A., \& Rees-Miller, J. (2005). Contemporary Linguistics: An Introduction, $5^{\text {th }}$ ed. NewYork: Bedford/St. Martin's.

Singleton, Jr., Royce, A. \& Sraits, B. C. (1999). Approaches to Social Research, $3^{\text {rd }}$ ed. New York: Oxford University Press.

\section{ACKNOWLEDGEMENT}

The research which discusses political metaphors in mass media and its persuasive effect towards readers is supported by some institutions. The appreciation is dedicated to the Rector, the Dean of the Faculty of Letters, and the Research and Social Services Department of Widya Mandala Catholic University, Madiun that support the process of conducting the research. Next, the huge gratitude is also dedicated to the Ministry of Research, Technology and Higher Education of Republic of Indonesia which had already given the research grant via the scheme of research for beginner (Penelitian Dosen Pemula) in the period of 2015. The gratitude is also given to the Department of Communication and Information of East Java Province and the Health Department of the City of Cimahi of West Java Province for the permission to collect the data by using questionnaire for the respondents to complete the data of the research. The research about political metaphors in Indonesian mass media is hoped to give valuable scientific contribution for the research in linguistics and pragmatics. It is also aimed to contribute social benefit for society especially for the script writing of political news in Indonesian journalism. 